Journal of The Indonesian Nutrition Association p-ISSN: 0436-0265 e-ISSN: 2528-5874

http://ejournal.persagi.org/index.php/Gizi_Indon

\title{
ANALISIS HASIL JANGKA PENDEK PELAKSANAAN KONSELING PEMBERIAN MAKAN BAYI DAN ANAK MENGGUNAKAN PEMODELAN RASCH
}

\author{
Analysis of Short-Term Outcome of The Infant And Young Child Feeding Counseling \\ Using Rasch Model
}

\author{
Fitria Nurwulansari ${ }^{1}$, Deni Kurniadi Sunjaya², Dida Akhmad Gurnida ${ }^{3}$ \\ ${ }^{1}$ Prodi Magister Kebidanan Fakultas Kedokteran Universitas Padjajaran \\ 2Departemen IImu Kesehatan Masyarakat Fakultas Kedokteran Universitas Padjajaran \\ 3Departemen IImu Kesehatan Anak Fakultas Kedokteran Universitas Padjadjaran/Rumah Sakit Umum \\ Pendidikan Hasan Sadikin \\ E-mail: fitrianurwulansari@ymail.com
}

\section{ABSTRACT}

The first thousand days of life is a golden period that determines the quality of life in the future. Practice of Infant and Young Child Feeding (IYCF) that are not appropriate during this period can cause stunting. One of the government's efforts to improve IYCF practice is IYCF Counseling. IYCF counseling can improve knowledge, attitude, and encourage the occurance of IYCF behavior. This study aims to analyze the short results of IYCF counseling on the knowledge and attitude of Mothers who have and have not been given IYCF counseling in Cireunghas District, Sukabumi. The instrument was used a modified knowledge and attitude questionnaire about IYCF. Rasch modeling was used for analysis of questionnaire data, the design of this study was a survey method with a cross sectional approach in April 2018 with maternal subjects having children aged 6-23 months totaling 90 people. The items on the instrument are found to have varying discrimination, which indicates that the instrument has the ability to measure. The results show that the counseling material that needs to be emphasized during IYCF counseling is about giving breastfeeding using bottles, giving up to 2 years of breastfeeding, the texture of food at the beginning of complementary feeding, and responsive feeding. There needs to be increase in the quality and frequency of IYCF counseling to achieve the expected changes of knowledge and attitude.

Keywords: IYCF counseling, knowledge, attitude, Rasch model

\section{ABSTRAK}

Seribu Hari Pertama Kehidupan (1000 HPK) merupakan periode emas yang menentukan kualitas kehidupan di masa yang akan datang. Praktik Pemberian Makan Bayi dan Anak (PMBA) yang tidak tepat pada masa tersebut dapat menyebabkan terjadinya stunting. Salah satu upaya pemerintah dalam meningkatkan praktik PMBA yaitu dengan konseling PMBA. Konseling PMBA dapat meningkatkan pengetahuan, sikap, dan mendorong terjadinya perilaku PMBA sesuai rekomendasi. Penelitian ini bertujuan untuk menganalisis hasil jangka pendek dari pelaksanaan konseling PMBA pada pengetahuan dan sikap ibu yang sudah dan belum diberikan konseling PMBA di Kecamatan Cireunghas Kabupaten Sukabumi. Instrumen yang digunakan adalah kuesioner pengetahuan dan sikap tentang PMBA yang telah dimodifikasi. Pemodelan Rasch digunakan untuk analisis data kuesioner, desain penelitian ini adalah metode survei dengan pendekatan waktu cross sectional pada bulan April 2018 dengan subjek ibu yang mempunyai anak usia 6-23 bulan yang berjumlah 90 orang. Item pada instrumen didapati mempunyai daya diskriminasi yang beragam, yang menunjukkan instrumen mempunyai kemampuan mengukur. Hasil analisis menunjukkan bahwa materi konseling yang perlu ditekankan pada saat konseling PMBA yaitu tentang pemberian ASI menggunakan botol, pemberian ASI hingga 2 tahun, tekstur makanan pada awal MP-ASI, dan responsive feeding. Perlu adanya peningkatan kualitas dan frekuensi dari konseling PMBA untuk mencapai perubahan pengetahuan dan sikap yang diharapkan.

Kata kunci: konseling PMBA, pengetahuan, sikap, pemodelan Rasch 


\section{PENDAHULUAN}

G izi seimbang selama periode konsepsi hingga dua tahun pertama kehidupan anak merupakan dasar bagi perkembangan potensi anak. ${ }^{1}$ Anak yang mengalami kekurangan gizi pada masa 1000 hari pertama kehidupan (HPK) akan mengalami masalah neurologis, penurunan kemampuan belajar, penurunan produktivitas, dan kemampuan bekerja, selanjutnya dapat meneruskan rantai kekurangan gizi pada generasi selanjutnya. ${ }^{2}$

WHO (World Health Organization) merekomendasikan Pemberian Makan pada Bayi dan Anak (PMBA) yang tepat meliputi Inisiasi Menyusu Dini (IMD) segera setelah lahir minimal selama 1 jam, pemberian Air Susu lbu (ASI) eksklusif sampai usia 6 bulan, memberikan Makanan Pendamping ASI (MPASI) mulai usia 6 bulan, dan meneruskan pemberian ASI sampai usia 2 tahun atau lebih. ${ }^{3}$ Hasil Riset Kesehatan Dasar (Riskesdas) tahun 2013 menunjukkan bahwa pemberian makanan pralakteal banyak diberikan kepada bayi baru lahir diantaranya pemberian susu formula $(79,8 \%)$, madu $(14,3 \%)$, dan air putih $(13,2 \%){ }^{4}$ Selain itu, pemberian makanan pendamping ASI seringkali terlalu dini, tidak memenuhi zat gizi, tidak higienis, dan cara pemberiannya belum tepat seperti melakukan tekanan atau memenuhi kemauan anak untuk mengkonsumsi makanan yang ia inginkan. ${ }^{5}$

Kurangnya pengetahuan dan informasi yang diperlukan terutama selama periode pemberian MP-ASI merupakan penyebab kritis dari rendahnya kualitas dan tidak tercukupinya kebutuhan makanan anak. Mempertimbangkan pentingnya gizi pada 1000 HPK, maka intervensi gizi pada kelompok sasaran 1000 HPK merupakan prioritas utama untuk meningkatkan kualitas kehidupan generasi yang akan datang. ${ }^{6}$ Hasil literatur review di negaranegara berkembang oleh Shi $\mathrm{L}$ et al. menyatakan bahwa intervensi pendidikan memberikan efek positif terhadap pengetahuan, sikap dan perilaku orangtua, serta asupan

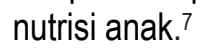

Rencana Pembangunan Jangka Menengah Nasional (RPJMN) bidang Kesehatan 20152019 telah menetapkan indikator sasaran kegiatan peningkatan status gizi masyarakat yaitu menurunkan prevalensi balita pendek menjadi 28 persen. Salah satu upaya untuk mencapai sasaran tersebut adalah mempromosikan pemberian MP-ASI yang tepat jumlah, kualitas, dan tepat waktu dengan melakukan konseling PMBA oleh tenaga kesehatan atau kader.8,9 Kementerian Kesehatan bekerjasama dengan MCA (Millenium Challenge Account) Indonesia melakukan pelatihan PMBA untuk tenaga kesehatan dan kader di 11 Provinsi dan 64 kabupaten/kota di Indonesia sejak tahun 2013. ${ }^{10}$

Kabupaten Sukabumi merupakan salah satu kabupaten pilot project MCA Indonesia dalam program konseling PMBA dengan prevalensi balita pendek di atas rata-rata nasional. Kabupaten Sukabumi terdiri dari 47 kecamatan, sedangkan yang memenuhi kriteria pelaksanaan pelatihan PMBA sebanyak 22 kecamatan, salah satunya adalah kecamatan Cireunghas. Wilayah kerja Puskesmas Cireunghas telah mempunyai 26 konselor PMBA yang terdiri dari tenaga kesehatan dan kader posyandu. Pada tahun 2017, Kecamatan Cireunghas masih mengalami permasalahan gizi kronis dengan persentase balita kurus 2,53 persen dan pendek sebanyak 25,12 persen. ${ }^{11}$

Tujuan dari konseling PMBA adalah untuk membantu klien agar mempunyai pengetahuan PMBA yang tepat sehingga dapat melakukan praktik PMBA sesuai rekomendasi. Faktor predisposisi suatu perilaku kesehatan meliputi pengetahuan dan sikap masyarakat terhadap kesehatan, tradisi dan kepercayaan masyarakat terhadap hal-hal yang berkaitan dengan kesehatan, sistem nilai yang dianut masyarakat, tingkat pendidikan, dan tingkat sosial ekonomi. ${ }^{12}$ Novita menjelaskan bahwa dengan meningkatnya pengetahuan seseorang dapat menimbulkan sikap positif dan kesadaran pada seseorang hingga terjadinya perubahan perilaku. Perubahan perilaku yang didasari kesadaran dan bukan karena paksaan akan bersifat langgeng/bertahan lama pada diri seseorang. ${ }^{13}$

Penelitian ini bertujuan untuk menganalisis hasil jangka pendek dari pelaksanaan konseling PMBA meliputi pengetahuan dan sikap ibu yang sudah dan belum mendapatkan konseling PMBA menggunakan pendekatan pemodelan Rasch. Diharapkan penelitian ini dapat menghasilkan informasi mengenai tingkat pemahaman ibu terhadap PMBA sehingga 
dapat dilakukan perbaikan pada kualitas pelaksanaan konseling PMBA.

\section{METODE PENELITIAN}

Penelitian dilaksanakan di Kecamatan Cireunghas Kabupaten Sukabumi pada bulan April 2018. Pemodelan Rasch digunakan untuk analisis data kuesioner, desain penelitian ini adalah metode survei dengan pendekatan waktu cross sectional. Perhitungan sampel menggunakan rumus perbandingan dua ratarata menghasilkan sejumlah 45 orang untuk masing-masing kelompok yang telah dan belum diberikan konseling PMBA. ${ }^{14}$ Rentang usia responden dari $19-28$ tahun dan sebagian besar responden (40\%) memiliki tingkat pendidikan Sekolah Dasar (SD). Penelitian ini telah mendapatkan persetujuan dari Komite Etik Penelitian Kesehatan Fakultas Kedokteran Universitas Padjajaran dengan Ethical Approval Nomor 203/UN6.KEP/EC/2018. Kriteria inklusi dalam penelitian ini adalah ibu yang sudah diberikan konseling PMBA dalam 6 minggu terakhir dan ibu yang belum pernah mendapatkan konseling PMBA. Kriteria eksklusi adalah ibu yang tidak berada di tempat saat penelitian. Peneliti telah mendapatkan persetujuan dari responden dengan menggunakan informed consent setelah responden mendapatkan penjelasan mengenai tujuan penelitian.

Pengukuran ini mengukur dua variabel yaitu pengetahuan dan sikap ibu tentang PMBA. Kuesioner yang digunakan adalah kuesioner dari penelitian Dewi M dan Aminah yang telah melalui proses analisis item. Dimensi dalam kuesioner tersebut yaitu variabel pengetahuan terdiri dari pemberian ASI dan pemberian MPASI, sedangkan variabel sikap terdiri dari pemberian MP-ASI. ${ }^{15}$ Oleh karena itu, kuesioner tersebut dimodifikasi sesuai dengan modul konseling PMBA, sehingga kuesioner pengetahuan dan sikap terdiri dari dimensi pentingnya PMBA, pemberian ASI, pemberian MP-ASI serta pemantauan pertumbuhan. Jenis skala yang digunakan untuk mengukur variabel pengetahuan adalah skala guttman dengan dua pilihan jawaban yaitu benar dan salah, sedangkan untuk variabel sikap adalah skala likert dengan empat pilihan jawaban yaitu sangat setuju, setuju, tidak setuju, dan sangat tidak setuju, serta terdiri dari pernyataan favorable dan unfavorable.

Jenis analisis untuk menilai pengetahuan dan sikap ibu menggunakan pemodelan Rasch. Pemodelan Rasch merupakan alat analisis yang dapat menguji validitas dan reliabilitas instrumen riset, bahkan dapat menguji kesesuaian person dan item secara simultan. Analisis pengujian validitas instrumen pada penelitian ini menggunakan pemodelan Rasch, hal yang dilihat adalah tingkat validitas respon pada item berdasarkan nilai Outfit Mean Square (MNSQ) yang diterima $0,5<$ MNSQ $<1,5$, Outfit Z-Standard (ZSTD) kesesuaian nilai uji $z$ yang diterima $-2,0<$ ZSTD $<+2,0$, dan Point Measure Correlation (Pt Mean Corr) 0,4< Pt Mean Corr $<0,85.11$ Apabila butir-butir item instrumen kualitas pelayanan memenuhi setidaknya satu kriteria di atas maka item instrumen layak digunakan. ${ }^{16}$ Kesimpulan dari uji validitas adalah dari 25 pernyataan pengetahuan sebanyak 3 item misfit yaitu nomor 19,20 , dan 22. Kemudian pernyataan nomor 20 dan 22 diperbaiki sedangkan pernyataan nomor 19 dihapus karena pernyataan lain sudah mewakili dimensi nomor 19. Sedangkan dari 16 pernyataan sikap sebanyak 2 item yang misfit yaitu nomor 7 dan 13. Kemudian dilakukan perbaikan terhadap item tersebut. Dengan demikian, instumen penelitian yang digunakan terdiri dari 24 pernyataan pengetahuan dan 16 pernyataan sikap.

Data mentah hasil pengukuran dari formulir pengumpulan data yang berbentuk skala ordinal kemudian ditransformasi menjadi skala interval menggunakan pemodelan Rasch dengan perangkat lunak Winsteps versi 4.10. Pemodelan Rasch mengatasi masalah keintervalan data dengan cara mengakomodasi transformasi logit, dengan menerapkan logaritma pada odd ratio data mentah yang didapatkan dari responden. Analisis univariat pada penelitian ini menunjukkan tingkat pengetahuan dan sikap tentang PMBA pada ibu yang mempunyai anak usia 6-23 bulan yang sudah dan belum diberikan konseling PMBA dilihat dari sebaran peta Wright item dan person yang dihasilkan dari Pemodelan Rasch.

\section{HASIL}

Responden pada penelitian ini berjumlah 90 orang, dengan karakteristik pendidikan, 
pekerjaan, dan sumber informasi tentang PMBA yang pernah didapatkan oleh responden. Berdasarkan Tabel 1 karakteristik pendidikan responden terbanyak berada pada tingkat SMP sebanyak 40 persen (sudah dikonseling) dan pada tingkat SD sebanyak 46,7 persen (belum dikonseling). Karakteristik pekerjaan responden terbanyak berada pada tidak bekerja/IRT sebanyak 71,1 persen (sudah dikonseling) dan 60 persen (belum dikonseling). Responden yang belum terpapar konseling PMBA sebanyak 51,1 persen mengatakan pernah mendapatkan informasi dari tenaga kesehatan seperti saat penyuluhan di posyandu, dan sebanyak 13,3 persen mendapatkan informasi dari media massa.

Hasil uji reliabilitas item pada instrumen pengetahuan adalah 0,73 (cukup) dan reliabilitas person yang diperoleh adalah 0,85 (bagus), sedangkan nilai Alpha Cronbach (KR20) yang mengukur interaksi antar person dan item menunjukkan nilai reliabilitas yaitu 0,88 . Nilai separasi item sebesar tiga mengandung makna bahwa terdapat tiga kelompok tingkat kesulitan item yang tergolong susah, sedang, mudah yang menunjukkan item baik karena bisa mendiskriminasi. Nilai separasi person tiga mengandung makna terdapat tiga kategori kelompok jawaban heterogen dari responden. Hasil separasi ini menunjukkan item dan person memiliki tingkat reliabilitas yang bagus.

Pada instrumen sikap, hasil uji reliabilitas item adalah 0,92 (bagus) dan reliabilitas person yang diperoleh adalah 0,72 (cukup), sedangkan nilai Alpha Cronbach (KR-20) yang mengukur interaksi antar person dan item menunjukkan nilai reliabilitas yaitu 0,75 . Nilai separasi item sebesar lima mengandung makna bahwa terdapat lima kelompok tingkat kesulitan item yang tergolong sangat susah, susah, sedang, mudah, sangat mudah yang menunjukkan item baik karena bisa mendiskriminasi. Nilai separasi person tiga mengandung makna terdapat tiga kategori kelompok jawaban heterogen yang dapat memisahkan tingkat persetujuan responden. Hasil separasi ini menunjukkan item dan person memiliki tingkat reliabilitas yang bagus.

Hasil uji validitas dan reliabilitas pada instrumen pengetahuan dan sikap menunjukkan bahwa data aktual yang diperoleh dalam uji instrumen penelitian sesuai dengan baik pada persyaratan pemodelan Rasch, sehingga instrumen penelitian layak (reliabel) untuk digunakan.

Tabel 1

Karakteristik Responden

\begin{tabular}{lcc}
\hline \multicolumn{1}{c}{ Karakteristik } & $\begin{array}{c}\text { Sudah } \\
\text { Dikonseling }\end{array}$ & $\begin{array}{c}\text { Belum } \\
\text { Dikonseling }\end{array}$ \\
\hline Usia & & \\
$-\quad<20$ tahun & $2(4,4 \%)$ & $1(2,2 \%)$ \\
$-\quad 20-35$ tahun & $37(82,2 \%)$ & $40(88,9 \%)$ \\
$-\quad>35$ tahun & $6(13,3 \%)$ & $4(8,8 \%)$ \\
Pendidikan ibu & & \\
$-\quad$ SD & $15(33,3 \%)$ & $21(46,7 \%)$ \\
$-\quad$ SMP & $18(40 \%)$ & $18(40 \%)$ \\
$-\quad$ SMA & $11(24,4 \%)$ & $6(13,3 \%)$ \\
$-\quad$ PT & $1(2,2 \%)$ & - \\
Pekerjaan ibu & & \\
$-\quad$ Bekerja & $13(28,9 \%)$ & $18(40 \%)$ \\
$-\quad$ Tidak bekerja/IRT & $32(71,1 \%)$ & $27(60 \%)$ \\
Sumber informasi & & \\
$-\quad$ Tidak pernah & $0(0 \%)$ & $16(35,6 \%)$ \\
$-\quad$ Tenaga kesehatan & $45(100 \%)$ & $23(51,1 \%)$ \\
$-\quad$ Media massa & $0(0 \%)$ & $6(13,3 \%)$ \\
\hline Jumlah & $45(100 \%)$ & $45(100 \%)$ \\
\hline
\end{tabular}


Berdasarkan peta Wright pada Gambar 1 dan 2 menunjukkan gambar sebelah kanan adalah peta kelompok ibu yang belum terpapar konseling PMBA, dan gambar sebelah kiri adalah kelompok ibu yang sudah diberikan konseling PMBA. Pada peta tersebut, terdapat kolom sebelah kiri adalah kolom person, dan kolom sebelah kanan adalah kolom item.

Pada Gambar 1, item yang berada di atas nilai rata-rata logit item $(+0,00$ logit $)$ mengandung arti bahwa item tersebut relatif sulit dijawab oleh responden dan item yang berada di bawah nilai rata-rata logit item mengandung arti item tersebut mudah dijawab oleh responden. Pada kolom pemberian ASI, item tersebar dari yang sangat mudah hingga item yang sangat sulit dijawab responden. Hal tersebut menunjukkan bahwa item-item tersebut memiliki daya diskriminasi yang baik. Terdapat dua item yang berada pada kategori item yang sulit dijawab oleh kedua kelompok dengan kode A7 (+1,57 logit pada kelompok yang sudah

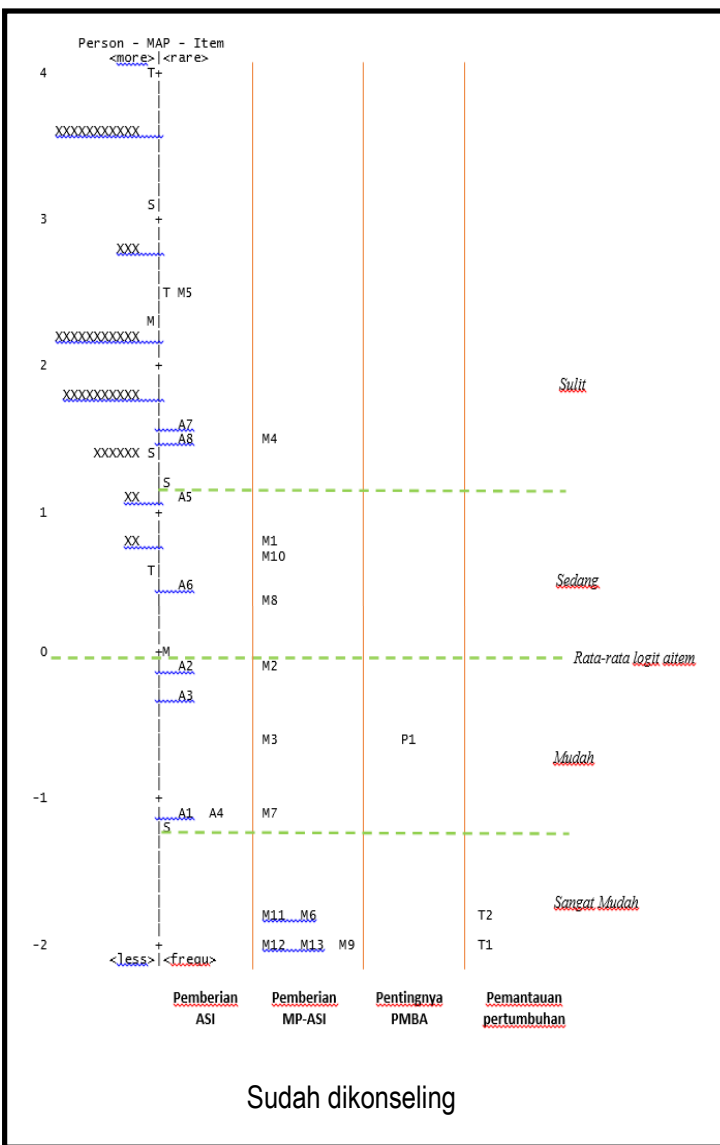

dikonseling dan $+1,99$ logit pada kelompok yang belum dikonseling) dan A8 (+1,45 logit pada kelompok yang sudah dikonseling dan $+1,03$ logit pada kelompok yang belum dikonseling). Item-item tersebut merupakan satu kelompok konstruk mengukur hal yang sama, mengandung arti bahwa item-item tersebut memiliki tingkat diskriminasi yang relatif sama, karena hasil pengukuran menunjukan nilai logit yang kurang lebih sama. Item A7 berisi pernyataan tentang pemberian ASI pada bayi menggunakan botol, artinya pengetahuan responden yang sudah maupun yang belum diberikan konseling PMBA masih kurang tentang risiko penggunaan botol pada bayi. Item A8 berisi pernyataan tentang "Pemberian MPASI diiringi dengan pemberian ASI hanya sampai anak berusia 1 tahun saja". Hal tersebut bermakna bahwa pengetahuan responden yang sudah maupun yang belum diberikan konseling PMBA masih kurang tentang pemberian ASI yang dianjurkan hingga dua tahun.

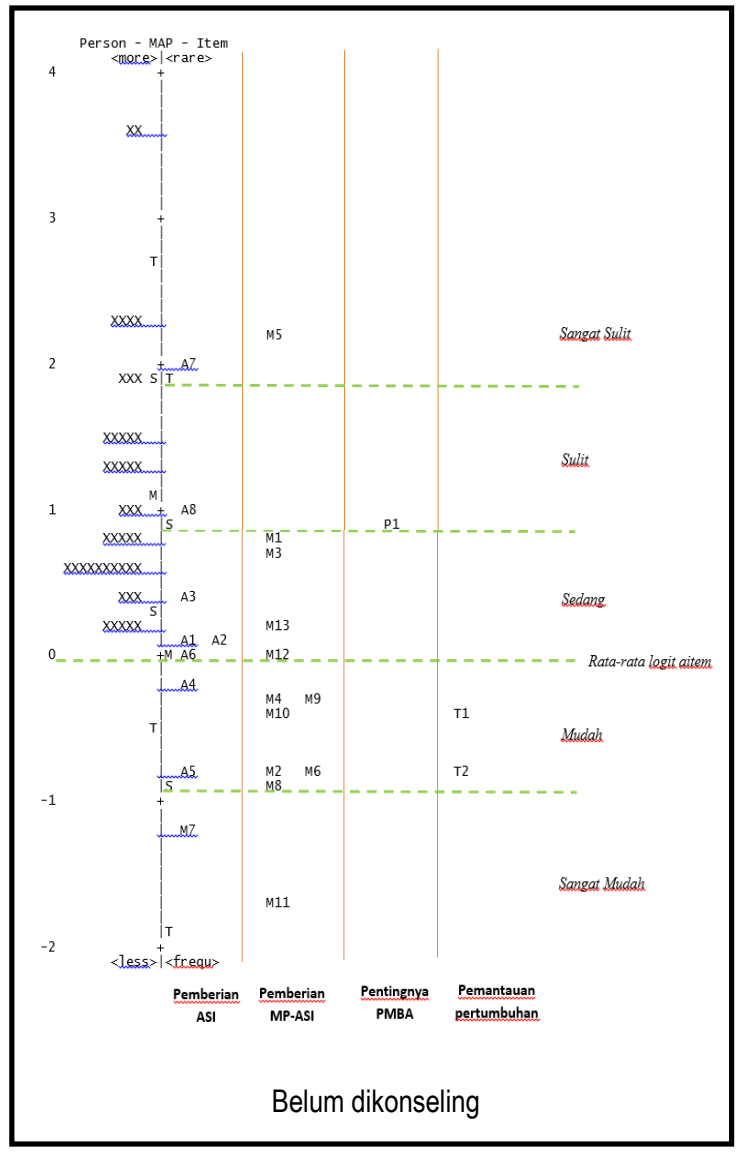

Gambar 1

Peta Wright Dimensi Pengetahuan 


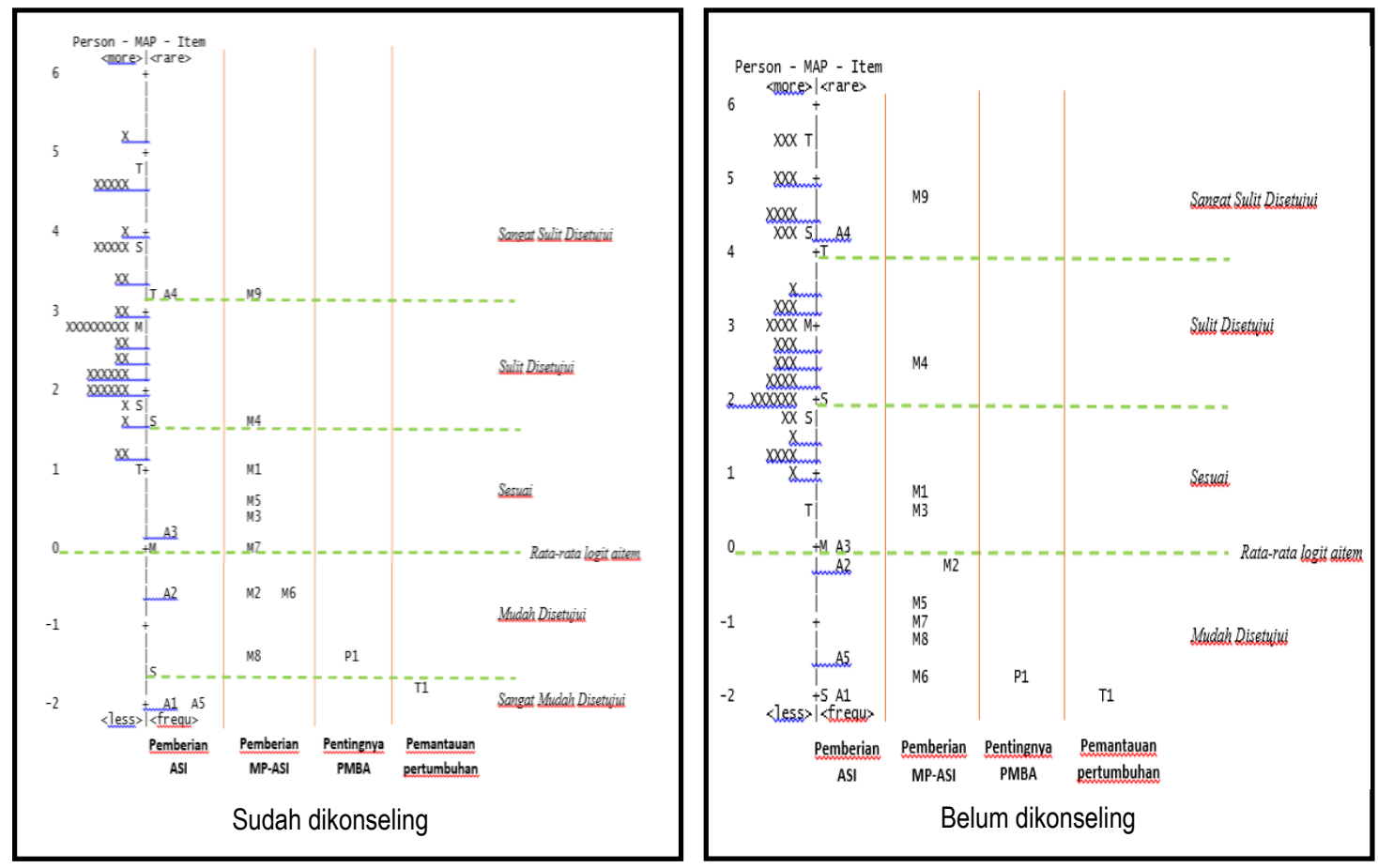

Gambar 2

Peta Wright Dimensi Sikap

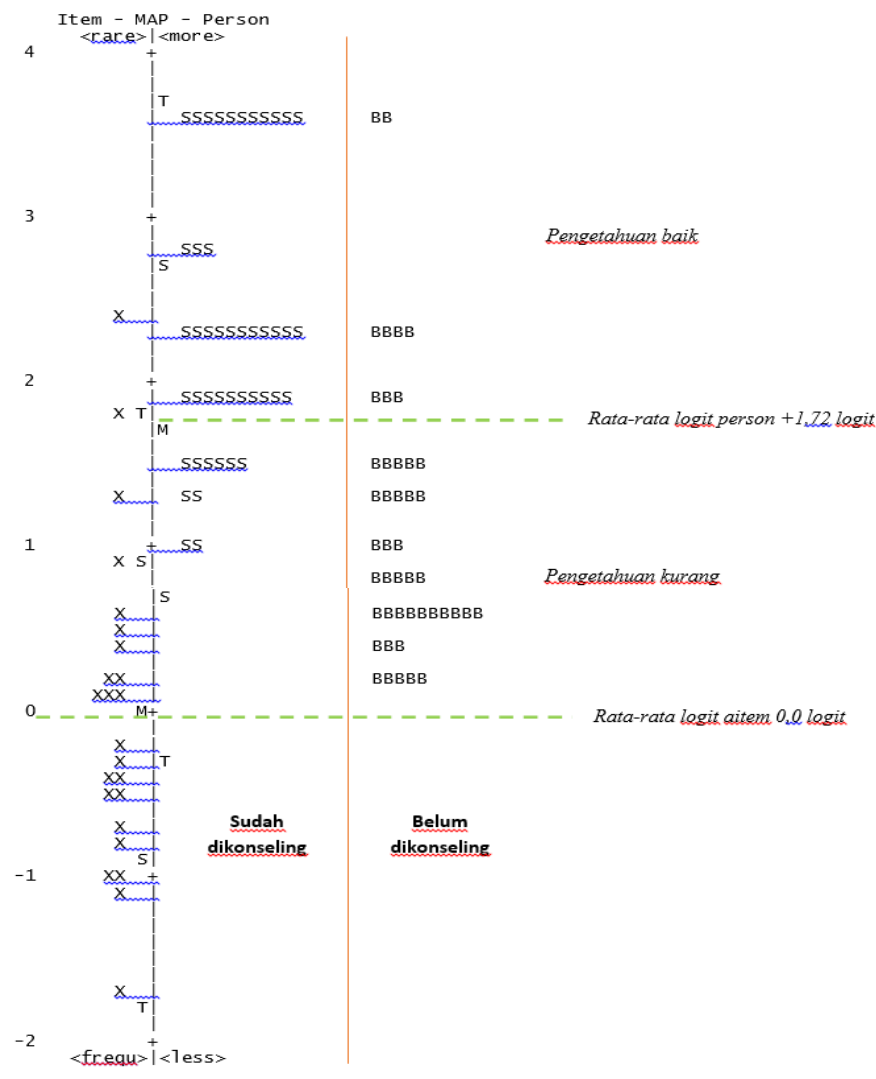

Gambar 3

Peta Wright Pengetahuan Responden 


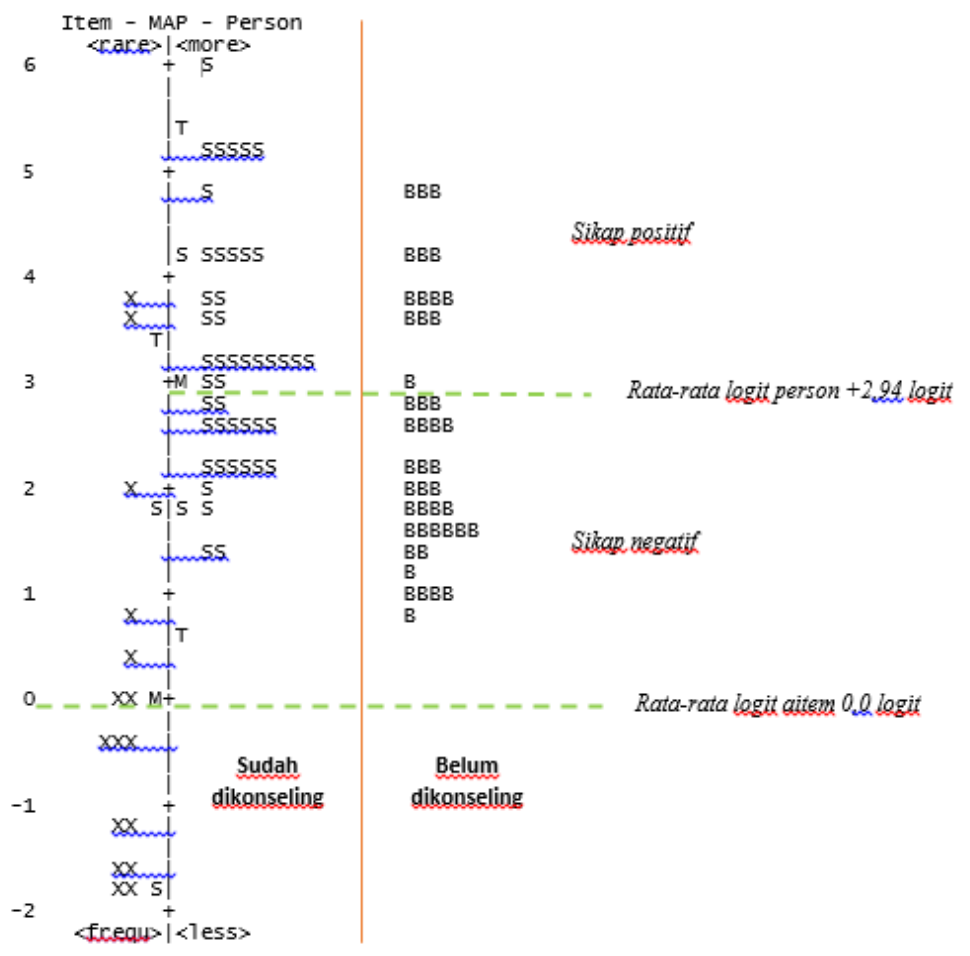

Gambar 4

Peta Wright Sikap Responden

Pada kolom pemberian MP-ASI, item tersebar dari yang sangat mudah hingga item yang sangat sulit dijawab responden. Hal tersebut menunjukkan bahwa item-item tersebut juga memiliki daya diskriminasi yang baik. Terdapat satu item yang berada pada kategori item yang sulit dijawab oleh responden yang sudah maupun belum diberikan konseling yaitu item M5. Pernyataan pada item tersebut yaitu "Pada saat enam bulan, makanan pertama yang dimakan bayi hendaknya memiliki tekstur seperti ASI sehingga bayi dapat menelan dengan mudah". Hal tersebut bermakna bahwa responden yang sudah maupun yang belum diberikan konseling belum paham bahwa pemberian makanan pada awal MP-ASI sebaiknya dengan tekstur cukup kental.

Item pernyataan pada pentingnya PMBA merupakan item yang mudah dijawab oleh kelompok yang sudah diberikan konseling PMBA $(-0,65$ logit), namun sulit dijawab oleh kelompok yang belum mendapatkan konseling PMBA (+0,93 logit). Hal tersebut bermakna bahwa konseling PMBA meningkatkan pengetahuan responden mengenai pentingnya PMBA.
Kolom pemantauan pertumbuhan terdiri dari dua item pernyataan. Pernyataan tersebut berkaitan dengan pemantauan pertumbuhan anak di posyandu. Item tersebut merupakan item yang dirasa mudah baik bagi kelompok yang sudah maupun yang belum diberikan konseling PMBA. Hal tersebut bermakna bahwa pengetahuan responden tentang pemantauan pertumbuhan sudah baik.

Pada Gambar 2, item yang berada di atas nilai rata-rata logit item $(+0,00$ logit) mengandung arti bahwa item tersebut relatif sulit disetujui oleh responden dan item yang berada di bawah nilai rata-rata logit item mengandung arti item tersebut mudah disetujui oleh responden. Pada kolom pemberian ASI, item tersebar dari yang sangat mudah disetujui hingga item yang sulit disetujui responden. Hal tersebut menunjukkan bahwa item-item tersebut memiliki daya diskriminasi yang baik. Terdapat satu item yaitu item A4 yang berada pada kategori item yang sulit dijawab oleh responden yang sudah $(+3,21$ logit) maupun yang belum $(+4,15$ logit) diberikan konseling. Item tersebut berisi pernyataan tentang pemberian ASI pada bayi menggunakan botol, artinya responden masih ada yang memberikan ASI kepada bayi 
menggunakan botol. Pada kolom pemberian MP-ASI, item tersebar dari yang mudah hingga item yang sangat sulit disetujui responden. Hal tersebut menunjukkan bahwa item-item tersebut memiliki daya diskriminasi yang baik dibanding dimensi lainnya. Terdapat dua item yang berada di atas rata-rata nilai logit yaitu item M4 dan M9. Item M4 sulit dijawab baik oleh responden yang sudah $(+1,66$ logit) maupun yang belum $(+2,48$ logit) diberikan konseling. Pernyataan item M4 yaitu "Saya merasa pemberian bubur dengan tekstur cukup kental baik diberikan pada awal MP-ASI", artinya responden yang sudah maupun yang belum diberikan konseling PMBA masih ada yang memberikan makanan dengan tekstur cair pada awal MP-ASI. Selain itu, item M9 yang berisi pernyataan tentang perilaku responsive feeding pada anak merupakan item yang sangat sulit disetujui baik bagi responden yang sudah $(+3,16$ logit) dan yang belum $(+4,70$ logit) diberikan konseling PMBA. Hal tersebut bermakna bahwa responden yang sudah maupun yang belum diberikan konseling belum memahami responsive feeding dengan baik.

\section{Pernyataan-pernyataan pada dimensi pentingnya PMBA dan pemantauan pertumbuhan merupakan item yang mudah disetujui baik oleh kelompok yang sudah maupun yang belum diberikan konseling PMBA. Hal tersebut bermakna bahwa responden setuju dengan dimensi tersebut.}

Berdasarkan peta Wright tentang tingkat pengetahuan dan sikap responden menunjukkan kolom sebelah kiri adalah kolom item, dan kolom sebelah kanan adalah kolom respoden. Tingkat pengetahuan dan sikap responden yang berada di atas nilai rata-rata logit person mengandung arti bahwa responden tersebut memiliki pengetahuan yang baik dan sikap positif, dibandingkan dengan responden yang berada di bawah nilai rata-rata logit person.

Berdasarkan sebaran peta wright Gambar 3 menunjukkan bahwa persentase responden yang memiliki pengetahuan baik tentang PMBA lebih besar pada kelompok yang telah diberikan konseling $(77,8 \%)$ daripada kelompok yang belum diberikan konseling (20\%). Gambar 4 menunjukkan bahwa persentase responden yang memiliki sikap positif terhadap PMBA lebih besar pada kelompok yang telah diberikan konseling $(60 \%)$ daripada kelompok yang belum diberikan konseling $(31,1 \%)$.

\section{BAHASAN}

Hasil pada penelitian ini menunjukkan bahwa konseling PMBA mempengaruhi tingkat pemahaman responden tentang pentingnya praktik pemberian makan bayi dan anak yang tepat. Hal tersebut terlihat pada perbedaan nilai logit item P1 yang lebih rendah pada responden yang sudah dikonseling dibanding nilai logit P1 pada responden yang belum dikonseling. Praktik pemberian makan bayi dan anak yang kurang optimal secara signifikan berhubungan dengan prevalensi balita stunting dan gizi kurang. ${ }^{17}$ Kelompok 1000 HPK penting untuk mengetahui manfaat dari perilaku PMBA yang tepat. Menurut teori Health Belief Models, seseorang akan berperilaku kesehatan dengan mempertimbangkan manfaat yang dirasakannya. ${ }^{18}$ Apabila ibu mengetahui manfaat perilaku PMBA yang tepat maka kemungkinan besar ibu akan memberikan makanan kepada anaknya sesuai rekomendasi.

Pengetahuan merupakan faktor predisposisi dari suatu perilaku kesehatan. ${ }^{12}$ Pengetahuan tentang pemberian makan bayi dan anak (PMBA) yang baik berhubungan dengan asupan nutrisi anak. ${ }^{19}$ Pengetahuan dapat didapatkan salah satunya dengan pendidikan gizi. Penelitian yang dilakukan oleh Dewi dan Aminah dengan melakukan edukasi gizi pada ibu balita stunting menggunakan booklet PMBA menunjukkan hasil bahwa terdapat perbedaan rata-rata yang bermakna pada skor pengetahuan sebelum dan setelah intervensi pada kedua kelompok. ${ }^{15}$

Pada penelitian ini, terdapat beberapa hal yang belum dipahami baik oleh kelompok yang sudah maupun yang belum diberikan konseling PMBA diantaranya tentang pemberian ASI menggunakan botol, pemberian ASI hingga 2 tahun, tekstur makanan pada awal MP-ASI yang dianjurkan, dan responsive feeding. Pemberian ASI menggunakan botol biasanya dikaitkan dengan peningkatan risiko penyakit, terutama penyakit diare, karena kesulitan mensterilkan dot dengan baik. 20 Penelitian yang dilakukan oleh $\mathrm{Li}$ et al. menunjukkan bahwa praktik pemberian susu menggunakan botol selama masa bayi memiliki efek jangka panjang terhadap perilaku pemberian makan 
oleh ibu dan perilaku makan anak kelak. Penggunaan botol ASI yang sering dilakukan ibu meningkatkan kemungkinan ibu untuk memberi tekanan pada anak untuk makan dan menyebabkan rendahnya sikap responsif anak. ${ }^{21}$

WHO merekomendasikan pemberian ASI Eksklusif selama 6 bulan pertama dan pemberian ASI diteruskan hingga anak berusia 2 tahun untuk meningkatkan daya tahan tubuh anak dan mengurangi risiko kontaminasi dari makanan/minuman selain $\mathrm{ASI}^{22}$ Pemberian ASI Eksklusif dan meneruskan pemberian ASI hingga 2 tahun juga dapat mempercepat pengembalian status gizi ibu, menurunkan risiko obesitas, hipertensi, rematoid artritis, kanker payudara ibu. ${ }^{23}$ Menurut rekomendasi PMBA, bayi sebelum usia 6 bulan hanya diberi ASI saja sedangkan setelah 6 bulan bayi harus diberi makanan tambahan namun jumlah, tekstur, frekuensi, dan jenis makanan harus sesuai dengan kebutuhan gizi anak. Tekstur makanan pada awal MP-ASI yang dianjurkan yaitu tekstur yang cukup kental, apabila sendok dibalikkan, makanan tidak langsung jatuh. ${ }^{8}$ Namun, ibu masih berpikir bahwa bayi pada awal MP-ASI sebaiknya diberikan makanan cair untuk mempermudah bayi menelan. Praktik pemberian makan yang tidak tepat pada bayi dan anak tersebut dapat berdampak pada terjadinya gagal tumbuh (growth faltering) pada anak. ${ }^{24}$

Penelitian ini menunjukkan sebagian ibu tidak menerapkan prinsip responsive feeding yaitu pemberian makan secara aktif. Pemberian makan secara aktif/responsif adalah bersikap perhatian dan responsif terhadap tanda-tanda yang disampaikan anak bahwa ia siap untuk makan, ibu memberikan dorongan secara aktif kepada anak untuk makan, tetapi tidak memaksanya. Bila anak makan sendiri, mungkin anak tidak akan kenyang karena gampang terganggu. Oleh sebab itu, anak perlu bantuan. Bila anak tidak mendapatkan makanan yang cukup, maka anak akan mengalami

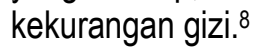

Penelitian yang dilakukan oleh Rahmawati dkk juga menunjukkan bahwa tingkat pengetahuan ibu terkait gizi untuk 1000 HPK masih kurang. Pengetahuan merupakan salah satu kunci perubahan perilaku. Tingkat pengetahuan ibu tentang ASI Eksklusif dan pemberian MP-ASI yang sesuai umur dan tahapannya dipengaruhi oleh beberapa faktor, antara lain keterpaparan informasi kesehatan, umur, dan peran dari tenaga kesehatan dalam melakukan sosialisasi informasi kesehatan. ${ }^{25}$

Penelitian yang dilakukan oleh Saridewi menunjukkan bahwa ibu bekerja dengan banyak kesibukan tetapi memiliki niat dan usaha untuk tetap memberikan ASI mendorong rasa optimis untuk mencari informasi. Oleh karena itu, perkembangan teknologi informasi, internet, dan media sosial menjadi alternatif media yang dapat digunakan untuk membantu menyebarkan edukasi gizi. ${ }^{26}$

Tingkat pendidikan ibu juga berpengaruh terhadap tingkat pengetahuan. Tingkat pendidikan merupakan faktor sosial yang mempengaruhi bagaimana ibu akan bersikap dan berperilaku sehingga diharapkan dengan adanya edukasi tentang kesehatan dapat meningkatkan pengetahuan ibu. Selain itu diharapkan dengan adanya peningkatan pengetahuan ibu tentang pentingnya ASI Eksklusif dan pemberian MP-ASI sesuai umur dan tahapannya, ibu akan mempunyai keinginan untuk merubah sikap dan perilakunya sesuai pengetahuan yang sudah didapat dan melakukan real action sebagai bentuk nyata dari perubahan perilaku yang diharapkan. Pemberian edukasi gizi merupakan salah satu faktor pengungkit untuk memperbaiki perilaku gizi menjadi lebih baik. ${ }^{27}$

Di samping itu, penyebab kurangnya pemahaman dan sikap seseorang meskipun telah diberikan konseling adalah intensitas konseling yang dilakukan. Semakin sering terjadi kontak antara ibu dan konselor maka semakin sering ibu mendapatkan informasi yang secara tidak langsung meningkatkan pengetahuan ibu. Hal tersebut sesuai dengan penelitian yang dilakukan oleh Ambarwati dkk dengan melakukan intervensi konseling laktasi intensif yaitu sebanyak 4 kali pada saat pranatal dan 5 kali pada saat postnatal berpengaruh terhadap peningkatan pengetahuan, perubahan sikap, dan peningkatan jumlah ibu yang memberikan ASI eksklusif sampai umur 3 bulan. Dengan demikian, untuk menghasilkan perubahan pengetahuan dan sikap agar sesuai dengan harapan, pelaksanaan konseling harus dilakukan secara terus-menerus. ${ }^{28}$

Perilaku pemberian makan bayi dan anak yang tepat sebaiknya disertai dengan kesadaran untuk memantau pertumbuhan anak. 
Hasil analisis pemodelan Rasch, responden memiliki pengetahuan dan sikap yang sudah baik pada dimensi pemantauan pertumbuhan. Seluruh responden pada kelompok yang sudah maupun yang belum diberikan konseling menjawab benar pernyataan dan menyetujui pernyataan yang ada pada dimensi tersebut. Berdasarkan hal tersebut dapat disimpulkan bahwa responden paham bahwa pemantauan pertumbuhan penting dilakukan. Tujuan dilakukannya penimbangan setiap bulan adalah untuk memonitor pertumbuhan anak, sehingga apabila diketahui adanya masalah sejak awal maka pencegahan dan penanganan dapat segera dilakukan sebelum balita jatuh ke gizi kurang atau bahkan gizi buruk. ${ }^{8}$

Keterbatasan pada penelitian ini, peneliti tidak melakukan analisis komparatif antar variabel serta tidak mempertimbangkan variabel perancu seperti pendidikan, pekerjaan, dan sumber informasi lainnya yang dapat mempengaruhi hasil pengukuran pengetahuan dan sikap.

\section{SIMPULAN DAN SARAN}

\section{Simpulan}

Setelah instrumen melalui tahapan uji validitas maupun reliabilitas menggunakan pemodelan Rasch, diketahui instrumen penelitian baik dalam mengukur pengetahuan dan sikap tentang PMBA di Kecamatan Cireunghas Kabupaten Sukabumi. Konseling PMBA memberikan dampak positif terhadap tingkat pemahaman responden tentang pentingnya pemberian makan bayi dan anak yang tepat. Materi konseling yang perlu ditekankan pada saat konseling PMBA yaitu tentang pemberian ASI menggunakan botol, pemberian ASI hingga 2 tahun, tekstur makanan pada awal MP-ASI, dan responsive feeding. Perlu adanya peningkatan kualitas dan frekuensi dari konseling PMBA untuk mencapai perubahan pengetahuan dan sikap yang diharapkan oleh program konseling PMBA.

\section{Saran}

Berdasarkan keterbatasan penelitian, penelitian selanjutnya disarankan untuk mengetahui perubahan pengetahuan, sikap, dan perilaku ibu yang telah diberikan konseling PMBA serta faktor yang mempengaruhinya baik secara kuantitatif maupun kualitatif.

\section{RUJUKAN}

1. De Onis M, Dewey KG, Borghi E, Onyango AW, Blössner M, Daelmans B, et al. The world health organization's global target for reducing childhood stunting by 2025: Rationale and proposed actions. Matern Child Nutr. 2013;9(S2):6-26.

2. Black R, Alderman H, Bhutta Z, Gillespie S, Haddad L, Horton S. Executive summary of The Lancet maternal and child nutrition series. Matern Child Nutr Study Gr (eds), Matern Child Nutr. 2013;1-12.

3. Kathyrn Dewey. Guiding Principles for Complementary Feeding of the Breastfed (PAHO and WHO). Pan Am Heal Organ World Heal Organ. 2001;18-25.

4. Badan Penelitian dan Pengembangan Kesehatan. Riset Kesehatan Dasar (RISKESDAS) 2013. Lap Nas 2013. 2013;1-384.

5. Utami NH, Fahmida U, Santika $O$. Unfavorable Infant Feeding Practices in East Lombok Have Not Yet Changed Much in the Last Decade. Penelit Gizi Makanan. 2011;34(1):75-85.

6. UNICEF. Gizi Ibu dan Anak. UNICEF Indones. 2012;1-6.

7. Shi L, Zhang J. Recent evidence of the effectiveness of educational interventions for improving complementary feeding practices in developing countries. J Trop Pediatr. 2011;57(2):91-8.

8. Kementerian Kesehatan Republik Indonesia. Modul Pelatihan Konseling: Pemberian Makan Bayi dan Anak. 2014;(21).

9. Kementerian Kesehatan RI. Laporan Info Situasi Balita Pendek. 2016;2442-7659. 
10. Rivani. Pelatihan pemberian makan bayi dan anak (PMBA) [Internet]. 2013. [cited 2018 Feb 02]. Available from: http://gizi.depkes.go.id/pelatihanpemberian-makan-bayi-dan-anak-pmba

11. Dinas Kesehatan Kabupaten Sukabumi. Laporan Tahunan Status Gizi Dinas Kesehatan Kabupaten Sukabumi. 2017.

12. Notoatmodjo S. Promosi kesehatan dan ilmu perilaku. Jakarta: Rineka cipta; 2012.

13. Novita YN. Promosi Kesehatan dalam Pelayanan Kebidanan. Jakarta: Salemba medika; 2013.

14. Negash C, Belachew T, Henry CJ, Kebebu A, Abegaz K, Whiting SJ. Nutrition education and introduction of broad bean - based complementary food improves knowledge and dietary practices of caregivers and nutritional status of their young children in Hula, Ethiopia. Food and Nutr Bull. 2014;35(4):480-6.

15. Dewi M, Aminah M. Pengaruh edukasi gizi terhadap feeding practice ibu balita stunting usia 6-24 bulan. Indones J Hum Nutr [Internet]. 2016 [cited 2018 Jan 30] ;3(1):1-8. Available from: http://ijhn.ub.ac.id/index.php/ijhn/article/vie w/138

16. Sumintono B. Aplikasi Model Rasch untuk Penelitian IImu-ilmu Sosial. 2014.

17. Imdad A, Yakoob MY, Bhutta ZA. Impact of maternal education about complementary feeding and provision of complementary foods on child growth in developing countries. BMC public health. 2011;11(Suppl 3).

18. Priyoto. Teori sikap dan perilaku dalam kesehatan. Yogyakarta: Nuha medika; 2014.

19. Hestuningtyas TR, Noer ER. Pengaruh konseling gizi terhadap pengetahuan, sikap, praktik ibu dalam pemberian makan anak, dan asupan zat gizi anak stunting usia 1-2 tahun di kecamatan semarang timur. J Nutr Coll. 2014; Volume 3,:17-25.

20. Badan Pusat Statistik. Survey Demografi dan Kesehatan Indonesia 2017. 2017;60. Available from: http://www.bps.go.id

21. Li R, Scanlon KS, May A, Rose C, Birch L. Bottle-Feeding Practices During Early Infancy and Eating Behaviors at 6 Years of Age. Pediatrics [Internet]. 2014;134(Supplement):S70-7. Available from:

http://pediatrics.aappublications.org/cgi/doi /10.1542/peds.2014-0646L

22. Kattula $D$, Sarkar R, Sivarathinaswamy $P$, Velusamy V, Venugopal S, Naumova EN, et al. The first 1000 days of life : prenatal and postnatal risk factors for morbidity and growth in a birth cohort in southern India. BMJ open. 2014; 4(7), e005404.

23. Eidelman, A. I., Schanler, R. J., Johnston, M., Landers, S., Noble, L., Szucs, K., \& Viehmann, L. Breastfeeding and the Use of Human Milk. Pediatrics. 2012;129(3), e827-e841.

24. IDAl. Rekomendasi praktik pemberian makan berbasis bukti pada bayi dan batita di Indonesia untuk mencegah malnutrisi. Unit kerja koordinasi nutrisi dan penyakit metabolik IDAI; 2015.

25. Rahmawati W, Wirawan NN, Wilujeng CS, Nugroho FA, Habibie IY, et al. Indonesian Journal of Human Nutrition. 2016;3(1):2031.

26. Saridewi VS. Menjaga ketahanan keluarga ( Studi Pada Anggota Grup Facebook Asosiasi Ibu Menyusui Indonesia ). Jurnal Ketahanan Nasional. 2016;22(1):76-93.

27. Kementerian kesehatan RI. Naskah Akademik Pedoman Gizi Seimbang (PGS). Jakarta; 2013. 
28. Ambarwati R, Muis SF, Susantini $P$. Pengaruh konseling laktasi intensif terhadap pemberian air susu ibu ( ASI ) eksklusif sampai 3 bulan. Jurnal Gizi Indonesia (The Indonesian Journal of Nutrition). 2013;2(1):16-23. 